\title{
Measuring Level of Voluntary Disclosures of Banks Listed in Bahrain Bourse
}

Mohamed Awadh* and Bahaaeddin Alareeni

MBA student, Ahlia University, Manama, Bahrain

\begin{abstract}
This study aims to measure level of voluntary disclosures (VD) in the annual reports of listed banks on Bahrain Bourse. The study sample consists of 24 listed banks during the period 2014-2015. A checklist was used to analyze the level of the VD. The results showed that there is a variation in the level of the VD among banks. It has been shown that the bank providing the most VD is the National Bank of Bahrain (70\%), and the bank providing the lowest level is Mashreq Bank (26\%). The overall level of VD in all banks in the market as a whole is $41 \%$. The most disclosed topic is general information about banks (54\%) and information about financial and non-financial analysis $(52 \%)$, such as share price $(100 \%)$ and historical information about the bank $(92 \%)$. The information that is the least disclosed concerns R\&D costs (23\%) and information about senior management (17\%).
\end{abstract}

Keywords: Voluntary disclosures; Bahrain bourse; Banks; Annual reports

\section{Introduction}

Disclosed information in annual reports can be divided into two types: accounting and voluntary disclosures. Accounting disclosures is required information by regulation that basically covers financial reports for banks, while voluntary disclosures is information that the bank is not forced to disclose, but it is bank initiative, which provides useful information to meet the needs of those who benefit from it [1-6].

Organizations around all over the world including banks are annually publishing financial reports in which they disclose a brief of different information of their practices for at least 2 years back. They are using it to keep and attract potential investors by comparing their performance of their last year with their past few years. The level and quality of disclosures determines the confidence needed by investors for their investment decisions. Therefore, the information and data disclosed in the financial reports of organizations and banks arena is essential source for investors to make wise investment decisions. As it is very important for investors to be certain about their investment decisions by assessing the performance level and forecasting the future [7]. In addition, the information and data disclosed has a strong effect on the functioning of financial markets [8].

The crises suffered by the major world banks have increased the need for disclosures as an element of control elements at the enterprise and its activities. For example, in 1998, Asia suffered a crisis in which it was recognized that disclosing information may decrease the possibility of a crisis due to increasing transparency in the banks. This has resulted in disclosures becoming an essential component of organizations [9].

Therefore, researchers have agreed that the more information that is disclosed, the higher the confidence level in the financial markets. Of course, this benefits not only investors but also the banks themselves as profits increase [10-12]. This is focused on the accounting profession affording confidence in the financial markets through the issuance of the International Accounting Standards Committee to several criteria. This defines the rules showing how the requirements of presentation and disclosure, such as International Standard No. $1 *$ (Presentation of Financial Statements); No. 24 (Related Party Disclosures); and No. 30 (Disclosures in the Financial Statements of Banks and Similar Financial Institutions) were replaced by the International Standard for
Financial Researching (7). In addition, the regulators also issued several requirements for the work of the financial markets, which strengthened the published quality of the financial statements.

In Bahrain, the Bahrain Bourse requires all listed companies to disclose their accounting information, but there is no empirical evidence as to whether they publish voluntary disclosures significantly and with a high level of appropriation. Since companies gain significant benefits by disclosing voluntary information, this can attract investors, which is reflected at an economic level.

To the best of our knowledge, there is no study that has examined the commitment level of voluntary disclosures in banks listed on Bahrain Bourse. Therefore, the adoption level of $\mathrm{c}$ disclosures by Bahraini banks is unknown. In addition, information in the voluntary disclosures may vary from bank to bank, depending on what they are obliged to disclose, what their investors need to know or what information is needed to attract potential investors. In Bahrain, banks are disclosing information other than mandatory information but in different levels and that it is the problem with this study which is how to measure the level of voluntary disclosures in the financial reports of banks listed on the Bahrain Bourse. In another word, this study is to certify which information have been disclosed, which information have been disclosed highly and which information have been disclosed slightly. This will have a significant impact on the decisions of several parties, including the organizers of the Bahrain Bourse and body securities as well as existing and potential investors. This is an analysis utilizing sample that demonstrates and measures the voluntary information published in the financial reports for the years 2014 and 2015. Based on the above, this study measures the level of the voluntary information disclosed by banks listed on the Bahrain Bourse.

*Corresponding author: Mohamed Awadh, MBA student, Ahlia University, Manama Bahrain, E-mail: mawadh@khcbonline.com

Received September 15, 2018; Accepted October 01, 2018; Published October 11,2018

Citation: Awadh M, Alareeni B (2018) Measuring Level of Voluntary Disclosures of Banks Listed in Bahrain Bourse. J Account Mark 7: 295. doi: 10.4172/21689601.1000295

Copyright: $\odot 2018$ Awadh M, et al. This is an open-access article distributed under the terms of the Creative Commons Attribution License, which permits unrestricted use, distribution, and reproduction in any medium, provided the original author and source are credited. 
In addition, it examines whether there is a difference in the level of the voluntary disclosures among banks listed on the Bahrain Bourse.

The study uses a comprehensive model (checklist) to measure the level of voluntary disclosures among banks listed on the Bahrain Bourse. The model includes multiple aspects, such as those related to disclosures of general information about the bank, its future status, the disclosures of human resources and disclosures of social responsibility and other aspects.

Section 1 being introduction, further part of this study is divided into five sections. Section 2 discusses theoretical framework and literature review. Section 3 presents the design and research methodology. Section 4 shows the descriptive statistics and analysis results. Section 5 presents the study's conclusion, recommendations and the scope for further research.

\section{Theoretical Framework and Literature Review}

An annual report is yearly disclosed information about the company. It is considered as a primary source of information. There are multiple types of annual reports, these are: the auditor's report, financial reports, the directors' reports and financial reports. This study focuses on financial reports. Financial reports are recorded information about the financial position and financial performance of the organization. This disclosed information is provided to meet specific parties needs. Financial reports can be divided into two types: accounting disclosures and voluntary disclosures [13].

\section{Accounting disclosures}

Hamad [14] stated that accounting disclosure is the attached notes to the financial statements dealing with clarification or detailed information on the items contained in the core of the financial statements. The aim of the financial statements should not be misleading, and can conceptually include the accounting methods used, the subsequent events to the date lists, analysis of the administration of past events and predictions as well as additional financials related to the company's activities. Marzooqi et al. [13] defined accounting disclosure as the receipt and transmission of information that has been prepared in the measurement stage for those who used and needed it, either within the organization or outside.

Hence, we must consider the importance of the information disclosed and the time that it's disclosed. Several studies defined accounting disclosure as information that organizations must disclose according to legal regulations Abeywardana et al. [15]. Other studies argue that accounting disclosure as a disclosure conducted by an organization listed on the stock exchange in their annual reports to meet the need of their regulatory authority $[16,17]$.

It is clear that the accounting disclosure focuses on communicating information to beneficiaries in order to accurately reflect the financial situation of the business. This would allow others to rely on that information in making decisions as well as to link the degree of disclosure and reduce uncertainty among beneficiaries through the distribution of all the economic information that it related to the project.

\section{Voluntary disclosure definition}

Many studies have dealt with the concept of voluntary disclosure; most of them agreed that voluntary disclosures are meant to add information and data on companies to inform decision-makers of the financial and non-financial information that serves to increase the compulsory legal disclosure requirements [4].
Hamada [4] defined voluntary disclosure as providing information about the company to increase the professional, legal and regulatory requirements, and it is the prerogative of the company's management whether or not to provide the appropriate information to outside parties. Voluntary disclosure was further defined as anything other than required information, disclosed by company's management, such as general accounting, securities and Bourse principles [16]. Basically, it involves disclosing information in addition to the accounting disclosures [18].

\section{Objective of voluntary disclosures}

Accounting disclosures mainly seek to meet the needs of all users of financial reports in order to help them in the decision-making process. This overall objective encompasses all kinds of disclosures; however, the goal of the voluntary disclosure or expansion of the disclosure is to increase communication with investors, thereby heightening their confidence in making accurate and objective decisions. Recommendation number 105, issued by the Financial Accounting Standards Board (FASB), has shown that effective disclosure works to describe items that are not recognized in the financial statements and the proposal of a proper scale, and serves to provide information to assist the parties in risk assessment. They also provide important information on the progress reports and any other accounting matters requiring study in general.

In other words, disclosing information assists the organizations in approving their reports by providing consistent information used for proper allocation of capital and reduced costs. Moreover, this information helps to increase the organization's stock prices $[19,20]$.

\section{Literature review}

Many previous studies have shown that there is a clear difference in the level of voluntary disclosures among listed banks in the financial markets. Some studies tried to explore the reasons for this discrepancy and to identify the factors that have an impact on the variation in the degree of voluntary disclosures in the published annual reports of these banks, others proposed a model (checklist) to measure the level or degree of voluntary disclosures of banks. This section presents and discusses the relationship between voluntary disclosures and other important factors (e.g., stock prices and liquidity, firm size, corporate governance, etc.), in addition, this section presents some benefits and advantages of voluntary disclosures:

Stock prices and liquidity: It has been reported that in 2008 the world wide has been affected by financial crisis since 1930 and that caused the banks' capital declination as a result of information lack. Jizi et al. [21] examined the relationship between bank's stock prices and corporate social responsibility disclosure. A content analysis method was used on a sample of national commercial banks during the period from 2009 to 2010. The results showed that there was a positive relationship between bank's stock prices and corporate social responsibility disclosure. In addition, the involvement of bank management and communicating with investors by disclosing information may prevent the bank from financial crises as the investors have sufficient information in which give them the trust and confident.

Moghaddam et al. [22] contributed another evidence on stock prices in relation to voluntary disclosure. The study used 55 organizations listed in Tehran Stock Exchange. The organizations are studied for a period from 1384 to 1390 years. A multivariate regression method was used. Findings of the research showed that there is a great positive relationship between stock prices and voluntary disclosure. 
The researcher stated that the higher information disclosed the more valuable organization will be in its market [22]. In addition, a study in conducted in Jordan examined voluntary disclosure relation to stock liquidity. A sample consists of 17 listed banks in Jordan. The research studied these bank for a period 2006 to 2014 . The voluntary disclosure was checked using a checklist of 33 items. The ordinary least square regression model was used to achieve the purpose of the research. The research specifies that higher voluntary disclosure lead to attract more investors as shares of liquidity increases. In another word, banks gain more investments from investors as increases in shares of liquidity by disclosing higher voluntary information [23].

In this regard, Asongu [24] aimed to investigate how banks managed liquidity after crises. He studied 20 out of 33 world banks, and information was collected from the World Wide Web. The researcher discovered that the financial liquidity market was greatly affected by the last crisis. Throughout the crisis, the disclosure of liquidity risk management was important to gain investor confidence. The research studied 16 disclosure information topics that were categorized into four main groups. The stakeholders of the organization should be provided with liquidity risk management information. The research showed that an inability to provide such information will not gain investors' trust in a financial crisis, which will lead to a meltdown.

The size: Some studies examined the relationship between voluntary disclosure and size of Banks for instance, a study was conducted by Khan et al. [25] in Ethiopian Banks. The study aimed to discover the relationship between voluntary disclosure and the size of the bank and the board. The study found that there is a high association between the voluntary disclosure and the size of the bank and the board. In another word, as bank disclose more voluntary information, the bank size become bigger and the board size will increase.

In the same regard, Ikpor et al. [13] studied the voluntary disclosure of banks in Nigeria for a period 2012 to 2013. The study aimed to identify the relation between the voluntary disclosure and the bank size. A multivariate analysis was used to find out the result. The study concluded that by disclosing more voluntary disclosure, banks can gain more investors which will lead to growth of the bank size. And as the bank size growth its cost of disclosing become less.

Further, Omar [26] aimed to determine the factors affecting the accounting transparency, such as bank earnings, size and obligation. The study was done on Islamic banks in Jordan. The research studied all Jordanian Islamic banks as well as three other banks: Aleinik Jordanian Islamic, Islamic International Arab Bank and Islamic Bank of Dubai and Jordan. Sample T-test and regression analysis was used. The findings showed that the accounting transparency in Jordanian Islamic banks as a whole is equal to $70 \%$, and the degree of accounting disclosure is $69 \%$. Other findings showed that bank size becomes bigger as accounting transparency increases. It was suggested that the Securities Exchange give more attention to accounting transparency.

Corporate governance: Abdullah et al. [27] studied 67 Islamic banks in Gulf Cooperation Council countries as well as in Southeast Asian to show the voluntary corporate governance disclosure. The study showed that the higher disclosure of voluntary corporate governance lead to a stronger corporate governance. Moreover, it has been resulted that there are factors affect the level of voluntary governance disclosures, these are: the banks size, the level of political and civil repression and the legal method. It has been recommended that Islamic banks need to improve their annual reports by disclosing information about corporate governance.
Age, complexity, and assets-in-place: A significant researcher has studied the relation between bank's size and assets-in-place and voluntary disclosure on 38 listed banks in India. An annual banks reported have been studies of one year (2002-2003). A checklist of 65 items of information have been used. The results viewed that there is a significant relationship between the bank's size and assets-in-place and voluntary disclosure. The researcher stated that with voluntary disclosure bank's management able to efficiently allocate the capital as well as efficiently control and manage their risk exposures effectively [28].

A study of Abeywardana et al. [15] aimed to identify the level of voluntary disclosure and its determinants. They used an index that included 83 topics and 9 subcategories. Information was gathered by analyzing the annual reports of the banking sector for the fouryear period of 2012 to 2015 . A panel data analysis was used to assess the determinants of voluntary disclosure levels. The results showed approximately $61 \%$ disclosures of general information, organization environment, economic performance and risk management. On the other hand, an average $45 \%$ included disclosed information about organization strategy, forecast information, human and intellectual capital, aggressive market and organization future and organizational social liability information. The results also showed that determinants of voluntary disclosure levels are organizational size, age, profits, authority and board independence. In addition, the organizational size, age and profits have a positive association while authority and board independence had a negative association.

Hossain et al. [29] empirically examined the determinants of voluntary disclosure in the annual reports of 25 listed firms of in the Doha Securities Market in Qatar. In addition, it examined the association between company specific characteristics and voluntary disclosure of the companies. A disclosure checklist consisting of 44 voluntary items of information was developed, and statistical analysis was performed using multiple regression analysis. The results indicated that age, size, complexity and assets-in-place are significant. In addition, it showed that the variable of profitability is insignificant in explaining the level of voluntary disclosure.

Economic benefits: Qiu et al. [30] studied the relation between organization's profitability and market value and environmental and social disclosures. The researcher found that the pervious organizations profitability was yield as a result of existing social disclosures; but it haven't find any relation between organizations profitability and social disclosures. On the other hand, investors do matter about organization social practices. And it has been found that there is a positive relationship between social disclosure and market values because cash flows in higher rates in those organizations. It has been recommended organization with high economic resources to make extensive disclosure to get positive economic benefits.

Reduction of cost of equity capital: A study investigates the relationship between the voluntary disclosure and the cost of equity capital. The study used 121 Swiss listed organizations. A Residual Income Valuation Model was used for the purpose of the study. The study showed a significant relationship between the voluntary disclosure and the cost of equity capital. The study results viewed that as organizations disclose higher level of voluntary information it cost of equity capital reduces [31]. In addition, an evidence from Europe, Australia and North America shows a high significant relation between cost of equity and voluntary disclosure after studying a 135 banks for 5 years and collected data from different sources, like, websites and bank's annual reports. This study found that the most item that 
lead to the reduction of the cost of equity. This item defined as risk management performance. Moreover, the study viewed that European banks have the highest reduction in their cost of equity as a result of improving their voluntary disclosure in comparing with Australia and North America [32].

Bank profitability: An evidence from United Kingdom and Irish was provided by significant researcher in which it studies the relationship between the voluntary disclosure and the increasing profits, impairments and leverage. The research stated that United Kingdom and Irish countries faces a financial crisis in which the organizations faces difficulties to stay in the market and the voluntary disclosure was expected a key solution for those organizations. A sample of 100 organizations from both countries are studied and analyzed using statistical regression methods and content analysis for the year 2009. The outcomes of the study showed that United Kingdom and Irish are disclosing $26 \%$ of voluntary disclosure and it has been found that there is a positive relationship between voluntary disclosure and the increasing profits, impairments and leverage. The research stated that the benefit of disclosing leverage information is to announce their effectiveness. While the reason for disclosing profitability information is to make sure the good share of price and to inform investors their ability to provide enhanced future outcomes which in-return lead to continuous profit to the organizations [33].

Another research was aimed to investigate and determine the relationship between bank profits and voluntary disclosures in Kenyan banks. An unweighted disclosure index of 40 topics was used to determine the level of disclosure. An ordinary least squares approach was used to analyze the data. Findings showed that the voluntary disclosure level of Kenyan banks was $62.8 \%$ on average. Results show that there is a positive and significant relationship between the bank's profit, listing status and size. It has been recommended that regulatory agencies in Kenya should require banks to disclose information in order to improve their disclosure levels [34].

Financial performance: A study aimed to view the relation between voluntary disclosure and financial performance. In order to calculate the financial performance, the research used return on equity (ROE). A 14 banks operating in Rwanda was used as sample in the research. The data collected from bank's annual reports for a period of 5 years (20112015) and it was analyzed using multiple linear regression method. The study shows a significant relationship between voluntary disclosure and financial performance as the results shows a $54 \%$ increase in financial performance as only $1 \%$ increase in financial disclosure. The research recommended that banks should disclose more information as it will return a high benefit to the bank [35].

Moreover, an investigation of the relationship between voluntary disclosures of financial performance and return on investment (ROI) was conducted. The sample used 10 listed organizations, including banks from the Nairobi Securities Exchange for the three-year period of 2011 to 2013. The methodology used was a checklist containing 49 voluntary disclosure topics. The study used the regression analysis to get the desired results. The results showed that there is a strong positive relationship between voluntary disclosures and financial performance, as the calculation of the Pearson Product Moment Correlation Coefficient $(R)$ is 0.6235 . The study recommended that banks need to increase voluntary information to gain cheaper capital as well as higher transparency and accountability, which leads to increased investor confidence in making decisions [20].

Wangari [24] examined 42 Kenyan commercial banks' annual reports for a period of six years (2008-2013). A disclosure index was developed with 47 disclosure data points collected from the banks' annual reports. A multiple linear regression model was used to analyze the data. The findings showed a positive association among the financials, the banks' futures and boards, social disclosures and investors' ROI. It has been shown that a $1 \%$ rise in financial disclosure leads to a $54 \%$ rise in the performance of commercial banks; a $1 \%$ rise in forward-looking disclosures leads to a $33.9 \%$ rise in ROI; and a $1 \%$ rise in board and social disclosures leads to a $50.3 \%$ rise in ROI. However, the results showed a negative relationship between general and strategic disclosures and return on equity, which means that a $1 \%$ rise in strategic disclosure leads to a $20.2 \%$ rise in return on equity of an organization. The research shows that organizations should increase disclosures of financial and social and board information in order to gain higher performance.

Market discipline and performance: A researcher studied a 38 listed bank in India. The research used a checklist of 184 items of which 88 items about mandatory and voluntary disclosures. The study found an average of 88 disclosed items of mandatory disclosure and 25 of voluntary disclosure. The research studied multiple attributes including market discipline. The findings of the research showed that there is a great positive relationship between voluntary disclosure and market discipline. As the researcher stated that it assists banks in allocating capital efficiently and in operating efficiently. Also, managing the risk exposures wisely [12].

Researchers aimed to indicate the effects of voluntary disclosures on securities exchange returns of organizations listed on the Nairobi Securities Exchange. The research studied 20 organizations for the five-year period of 2009 to 2013. A multiple linear regression analysis of the market performance of the organizations against voluntary disclosures, exchange rate, interest rate and rate of inflation was conducted. The findings showed that all factors have a positive effect on an organization's market performance. The study suggested that organizations should have voluntary disclosures in order to show higher stock returns [36].

Listing status: Hawashe [37] studied the relationship among seven commercial bank-specific characteristics (i.e., age of bank, size of bank, bank liquidity position, profitability, government ownership, foreign ownership and listing status) and the level of voluntary disclosures by listed banks. A regression analysis had been used to test the relationship between bank characteristics and voluntary disclosures. The findings showed that bank size and listing status were significantly associated with the level of voluntary disclosures, and the level of voluntary disclosures in annual reports are not influenced by other banking characteristics.

Additionally, another research aimed to study 130 of Croatia's medium and large organizations to determine the extent of voluntary disclosure in annual reports using explanatory analyses. The results showed that there are few organizations that disclosed insufficient voluntary information. In addition, organization size, listing status and industrial sector had a significant impact on the extent of voluntary disclosures. Conversely, the organization's profit and ownership structure were found to be insignificant [38].

Board structure: A research proposes to determine the disclosure of the accounting information level in organizations in Nigeria and to determine the organizations' factors that have an effect on the quality of disclosure. A structured questionnaire was used to obtain the needed information along with disclosure index to determine the disclosure 
level in the annual reports of the organizations. The study also examined the association between the extent of disclosures and the organizations' factors. A multi-linear regression model was used, and the results showed that the average of disclosing accounting information was high while the average of voluntary disclosures was very low. It was also shown that the organizations' profits, size, board structure and market discipline factors were significant while factors like organization age and the complexity of the business were not important factors to be disclosed [39].

Future forecast: Jankauskiene et al. [40] proposed to study publicly financial disclosure information to know whether it was applicable and dependable to forecast the bankruptcy of Snoras Bank. Therefore, there was an analysis of public disclosure by several sources: the bank itself, accountants, regulating organizations and mass media before the publication of the bank crisis. The findings showed that the Snoras Bank crisis was unexpected, and the crisis occurred because of insufficient and outdated financial disclosures. The disclosed information was not sufficient to predict the Snoras Bank crisis.

Another researcher aimed to determine how voluntary accounting disclosures can influence the investor's decisions in the market. The study was conducted on organizations listed on the Amman Stock Exchange in 2014, and was intended to determine how optional items on the accounting disclosure optional items influenced investors' decisions. For the purpose of the study, a questionnaire consisting of 54 topics was distributed. A package program for the social sciences had been used. The results showed that the voluntary accounting disclosure was able to influence the decisions of investors, and it also demonstrated that the forecast of profit and information for workers had the most influence on the decisions of investors.

Oluwagbemiga [41] aimed to show the use of voluntary disclosures in determining the quality of financial statements. The study focused on its effects on investor assessment and the organization's performance in Nigeria. The methodology of this study was a questionnaire for 140 individuals about 258 listed organizations. A calculation was done using Statistical Package for the Social Sciences (SPSS) software. The results demonstrated increased performance, and investor decision-making was facilitated due to voluntary disclosures. The results indicated that voluntary disclosures assist investors in making decisions, which can lead to optimal organizational performance.

Improve investor's evaluation: Zer [42] examines the causal consequence of voluntary disclosures on a bank's estimated default probability, enterprise risk and value. This research measured disclosure through a self-constructed index. The sample included 80 of the biggest U.S. banks during 1998 to 2011. The study showed that a bank's management did increase its voluntary disclosure in response to the deterioration of the information from external sources. The results further showed that an increase in voluntary disclosures led to improved investors' evaluation of the bank risk and value.

Disclosure level and quality: A research aimed to investigate the extent of voluntary information disclosures in 54 listed and unlisted Libyan commercial banks were been conducted by studying their annual reports for the period 2006 to 2011. A longitudinal analysis had been used to identify whether there is any important improvement in the voluntary information disclosure level. For the purpose of this research, a checklist was prepared with 63 voluntary information topics, and a dichotomous scoring technique was performed. An Ordinary Least Squares analysis demonstrated that the level of information disclosures is weak with an average equal to $38 \%$. In addition, the results showed that the level of background information is the highest level of voluntary disclosures, while the level of corporate social information is the lowest level of voluntary disclosure [43].

A significant researcher aimed to collect voluntary disclosure information in order to formulate an integrated model as well as test the prepared model in 22 organizations listed on the Damascus Securities Exchange for one year (2012). For the aim of this research, previous studies, as well as research related to the formulation of the model, were studied and then tested the disclosures of the listed organizations on the Damascus Securities Exchange. The results found that the model developed is acceptable, but it showed that the level of disclosure by organizations is very low as the highest disclosure was only $10 \%$ [4].

A determination of organization factors that were able to influence voluntary disclosure levels in a bank's annual reports in Ghana for one year (2009) were been examined. The factors that were studied were bank profit, size, debt equity percentage, liquidity and audit bank size. Descriptive analysis was used for the research along with regression analysis to analyze data. The findings specified that the relationship between profitability represented by Return on Capital Employed (ROCE) and disclosure level is positive, while debt equity percentage, liquidity, organization size and the organization's audit size were inconsequentially associated with the disclosure extent [44].

Bhasin et al. [45] aimed to study the level and determinants of the voluntary disclosure and its types of listed banks on the Kazakhstan Stock Exchange. The research studied the relationship between voluntary disclosure and organization factors, such as board size and structure, as well as how bank size and age affect difference in the voluntary disclosure index [46-48]. The research showed that the outside directors have an important positive influence on disclosure levels. However, the results showed that voluntary information does not actively improve [49-52].

Summary: All previous studies showed that the level of voluntary disclosure is to somehow low, but it has been determined that there are recommendations to pay more attention to it, since there are few who disclose the voluntary information in Arab countries. This of course, shows the lack of the studies to determine the level of voluntary disclosure in annual reports for banks in Arab countries, including Bahrain. Therefore, this study is a step forward towards providing a model for measuring the level of voluntary disclosure of banks listed on the Bahrain Bourse. It provides evidence about the level of voluntary disclosures, which includes multiple information that banks can disclose properly and that will benefit several parties. To the best of our knowledge, this is the first study in Bahrain that measures the level of the voluntary disclosures in the financial reports of the banks listed on the Bahrain Bourse.

\section{Study Methodology}

The needed data was collected from the annual reports of bank's listed in Bahrain Bourse. The study focused on the period of 2 years and that from 2014 to 2015 to avoid the changes caused by Bahrain regulatory or the competitive environment during the study period. The study used the content analysis method in the analysis of the level of the voluntary disclosure published in bank's annual reports. A suggested model for a list of questions (checklist) was used. This model has been found in multiple studies, such as those by Hamada et al. [4], and it has been modified to be suitable to Bahrain's environment. The proposed model contains 84 factors divided into eight topics: general information about banks, information about the audit committee, and 
board of directors, governance, senior management, financial and nonfinancial analysis, and employees of the bank, the social responsibility, environmental policies and research and developments costs. The model used to assist the researchers to express voluntary disclosure. It has taken advantage of those models used in previous studies because they contain a large number of important questions to measure the level of voluntary disclosures and their adoption in most parts of the financial researching standards. This checklist can be the useful model for the researchers as the most literature review shows that different banks in same country disclose different levels of voluntary disclosure and that may also be in case of Bahrain's banks.

\section{The study sample}

There are different sectors operating and listed on Bahrain Bourse, the researchers focused only on one sector and that is banking sector in order to be more creditable and accurate as different sectors provide different voluntary disclosure. Therefore, the study sample consisted of all banks listed on the Bahrain Bourse. Annual reports for the year 2014 and 2015 have been used for the study. However, the main criteria used for selection of the banks were: (I) annual reports must be available at Bahrain Bourse or the bank's website; and (II) the bank must have been listed throughout the study period. Therefore, the total number of banks covered under the study is 24 of Islamic and non-Islamic banks and these are: National Bank of Bahrain, Bank of Bahrain and Kuwait, Bahrain Islamic Bank, Standard Chartered Bank, Citibank, Ahli United Bank, Kuwait Finance House, Al Baraka Islamic Bank, Ithmaar Bank, Arab Bank, Khaleeji Commercial Bank, United Gulf Bank, Al-Salam Bank, BMI Bank, HSBC Bank Middle East, National Bank of Abu Dhabi, Habib Bank, Eskan Bank, State Bank of India, ICICI Bank, National Bank of Kuwait, BNP Paribas, Bahrain Development Bank and Mashreq Bank. Some of the banks are Bahraini banks and some other are non-Bahraini banks but they are operating in Bahrain.

\section{Study Results - Measurement of Voluntary Disclosures}

As previously mentioned, a checklist of 84 items of information have been used to examine the discloser level of banks listed in Bahrain
Bourse. These 84 information items have been divided into 8 topics as follows:

As presented in Table 1, the first topic is a general information about banks, in which it contains the basic information about the bank and the number of banks who provide such information. The table shows that highest disclosed information is a brief historical information about the bank (22 banks). The second highest disclosed information is bank statements (20 banks). While, 19 banks disclose a description of the main products and/or services offered as well as the awards gained by bank. Moreover, a description of the bank's marketing network for products and services and of insurance programs are disclosed by 17 banks. 16 banks disclose an analysis of the banks and branches. Like, an overview, a brief of historical perspective and their operations and contributions. In addition, 15 banks disclose an analysis of the bank's market share and the bank contribution to the national economy. Furthermore, methods and programs used for quality control are disclosed by 14 banks. 10 of the banks disclose the competitive situation in the industry; an analysis of the competitiors. Disclosure of the bank's customers and key suppliers as well as the importance issues during the year are disclosed by 9 banks. 7 banks disclose about the production capacity of the bank. The disclosure of general economic information and an explanation of the organizational structure of the bank are disclosed by 6 banks and only 2 banks disclose the effect of political and economic factors on the results of the bank's business.

The second topic of the checklist is information about the audit committee, their roles and practices. As is shown in Table 2, the highest item is disclosure about the functional role of the audit committee (21 banks) while, disclosure about the number of meeting held with the audit committee during the year as well as disclosure about the work carried out by them are the second highest disclosed item. And the third highest disclosed item is the number of members of the audit committee. Moreover, only 6 banks disclosing the names and qualifications of the members of the audit committee. However, there are no disclosure by any bank about the number of attendees at the meeting of the audit committee and disclosure of their independence.

\begin{tabular}{|c|c|c|c|}
\hline No & Disclosure Type & \# of Banks & $\%$ \\
\hline 1 & Disclosure of general economic information & 6 & $25 \%$ \\
\hline 2 & Disclosure of bank statements & 20 & $83 \%$ \\
\hline 3 & An explanation of the organizational structure of the bank & 6 & $25 \%$ \\
\hline 4 & Brief historical information about the bank & 22 & $92 \%$ \\
\hline 5 & The effect of political and economic factors on the results of the bank's business & 2 & $8 \%$ \\
\hline 6 & Description of the main products/services offered by the bank & 19 & $79 \%$ \\
\hline 7 & The analysis of the bank's market share & 15 & $63 \%$ \\
\hline 8 & Disclosure of the bank's customers and key suppliers & 9 & $38 \%$ \\
\hline 9 & Disclosure of the competitive situation in the industry (analysis of competitors) & 10 & $42 \%$ \\
\hline 10 & Description of the bank's marketing network for products and services & 17 & $71 \%$ \\
\hline 11 & The production capacity of the bank & 7 & $29 \%$ \\
\hline 12 & Description and analysis of investment projects & 12 & $50 \%$ \\
\hline 13 & Analysis of the banks and branches (overview, a brief historical perspective, operations, contributions) & 16 & $67 \%$ \\
\hline 14 & Description of insurance programs of the bank & 17 & $71 \%$ \\
\hline 15 & Methods and programs used for quality control & 14 & $58 \%$ \\
\hline 16 & Awards won by the bank & 19 & $79 \%$ \\
\hline 17 & The bank's contribution to the national economy & 15 & $63 \%$ \\
\hline 18 & Important issues during the year & 9 & $38 \%$ \\
\hline & Average Total & \multicolumn{2}{|c|}{$54 \%$} \\
\hline
\end{tabular}

Table 1: General information about banks. 
The third topic is disclosures of the board of directors, their general personal information and their practices. As is shown in Table 3, the highest disclosed information is the board director's names, ages and their address (18 banks). While the disclosure of the education and academic qualifications as well as number of meetings each year viewed the second highest disclosure (13 banks). The third highest disclosure is the extinct of board concern about competitive environment (10 banks). While 9 banks disclose about the board experience and skills. And only 4 banks disclose the amount of the board contribution and the methods of determining bonuses and compensation to the board itself.

The fourth topic is disclosure of governance. It can be seen in Table 4 that the most disclosed information is the number of meetings during the year ( 9 banks). The second most disclosed information is the members of the governance committee and their qualifications ( 8 banks). The third most disclosed information is the extent of the existence of the committee on corporate governance ( 7 banks). Additionally, 5 banks disclose the responsibilities of governance committee and the abiding by the rules of governance.

Table 5 presents the fourth topic related to disclosure about senior management and their personal information and their roles. As is shown in the table, the disclosure about the experience of managers was the most disclosed information ( 7 banks). While the information about the division of managers to executive and non-executive director were the second most disclosed information ( 5 banks). The disclosure about managers educational qualifications were the third most disclosed information (4 banks). However, there was no disclosure from any bank regarding the responsibility of managers in the preparation of financial research.

Table 6 shows the sixth topic concerning disclosure about financial and non-financial analysis. The table shows that all banks are disclosing information about the share price and they provide the statement of cash flows. 18 banks disclose statement of capital expenditures expected. Furthermore, 17 banks disclose information about fluctuations in foreign currency exchange rates during the year. A number of 16 banks are disclosing about banks loans and mortgages and their uses as well as about any new products and services. Moreover, information about expectations of profitability per share and a summary of financial statements of the last 3 years or more are disclosed by 18 banks. Besides, 14 banks are disclosing about the adjusted financial statements after taking into account inflation and its impact on it. Also, 12 banks are disclosing information about the impact of inflation on the future of the bank's operations, bank's forecasts of future sales and future profits. Information about the impact of the bank's strategy on future business results are disclosed by 8 banks. However, 7 banks are disclosing information about the expansion plan of sales, expected expenses for advertising and the research and development expenditure. Yet, information about the marketing plan and the plan's expansion in the distribution system are disclosed by 6 banks. Nevertheless, 5 banks are disclosing information that may affect the future performance of the bank. And only 2 banks are disclosing information about advertising expenses.

As mentioned below in Table 7, the seventh topic is information about employees of the bank and disclosure of social responsibilities

\begin{tabular}{|c|c|c|c|}
\hline No & Disclosure Type & \# of Banks & $\%$ \\
\hline 1 & Declaration of the functional role of the Audit Committee & 21 & $88 \%$ \\
\hline 2 & The names and qualifications of the members of the Audit Committee & 6 & $25 \%$ \\
\hline 3 & The number of members of the Audit Committee & 13 & $54 \%$ \\
\hline 4 & The number of meetings held with the Audit Committee during the year & 18 & $75 \%$ \\
\hline 5 & Number of attendees at the meetings of the Audit Committee & 0 & $0 \%$ \\
\hline 6 & Disclosure of the independence of the Audit Committee & 0 & $0 \%$ \\
\hline 7 & A study about work carried out by the Audit Committee & 18 & $75 \%$ \\
\hline & Average Total & \multicolumn{2}{|c|}{$45 \%$} \\
\hline
\end{tabular}

Table 2: Information about the audit committee.

\begin{tabular}{|c|c|c|c|}
\hline No & Disclosure Type & \# of Banks & $\%$ \\
\hline 1 & The names, ages and addresses of the Board of Directors & 18 & $75 \%$ \\
\hline 2 & The education and academic qualifications of the Board of Directors & 13 & $54 \%$ \\
\hline 3 & Experience and skills of the Board of Directors & 9 & $38 \%$ \\
\hline 4 & The extent of concern by the Board of Directors as to the competition by other banks & 10 & $42 \%$ \\
\hline 5 & The amount of the contribution of members of the Board of Directors (e.g., stocks, etc.) & 4 & $17 \%$ \\
\hline 6 & The number of meetings each year & 13 & $54 \%$ \\
\hline 7 & The methods of determining bonuses and compensation to the members of the Board of Directors & 4 & $17 \%$ \\
\hline & Average Total & \multicolumn{2}{|c|}{$42 \%$} \\
\hline
\end{tabular}

Table 3: Disclosures of the board of directors.

\begin{tabular}{|c|c|c|c|}
\hline No & Disclosure Type & \# of Banks & $\%$ \\
\hline 1 & The extent of the existence of the Committee on Corporate Governance & 7 & $29 \%$ \\
\hline 2 & Disclosure of the members of the Governance Committee and their qualifications & 8 & $33 \%$ \\
\hline 3 & The responsibilities of the Governance Committee & 5 & $21 \%$ \\
\hline 4 & The number of meetings during the year & 9 & $38 \%$ \\
\hline 5 & Information about abiding by the rules of governance & 5 & $21 \%$ \\
\hline & Average Total & \multicolumn{2}{|c|}{$28 \%$} \\
\hline
\end{tabular}

Table 4: Information about governance. 
and environmental policies. The highest disclosed information is about donations and grants (14 banks). The second highest disclosure is about bank social's contributions (13 banks). While the third highest disclosure is about employment rotation policy. Disclosure about classification of employees by gender, number of bonuses granted to employees and the policy for granting them, categories and the quality of the staff who have received training in the bank and the employment policies are all disclosed by 9 banks. Additionally, 8 banks are disclosing information about the educational qualifications of accountants. And 7 banks are disclosing about reasons for changing the number of employees. Also, 6 banks are disclosing about safety and security system as well as policy used in training. Information about the total number of employees for the last two years or more, the work accidents and the cost of safety and security procedures are disclosed by 5 banks. However, 4 banks are disclosing about social security policy. Nevertheless, only 3 banks are disclosing about the budget for staff training expenses and subsides and contributions to others. And one bank discloses information about environmental protection programs.

Finally, in Table 8 is presented the eighth topic concerning research and development costs. The most disclosed information is the research and development projects ( 9 banks). The second most disclosed information is the number of employees working in study and development, achieved results of it and the actual cost of research and development activities during last 2 years ( 6 banks). The third most disclosed information is the study and development policy (4 banks). However, only 2 banks are disclosing about the financial allocations for the study and development.
As shown in the Table 9, the highest percentage of voluntary information disclosed (54\%) relates to the general information about banks, the second highest is $52 \%$ relating to financial and non-financial analysis, and the third highest is $45 \%$ and relates to information about the Audit Committee (45\%). The lowest percentage of voluntary information disclosed is $17 \%$ and relates to information about senior management.

This provides evidence that there is a lack of willingness by banks to disclose information about senior management, R\&D costs, information about governance and bank employees and disclosure of social responsibility and environmental policies.

As shown in Table 10, the most disclosed information by banks are share price and statements of cash flow (100\%) with the second most disclosed information being historical information about the bank (92\%). The declaration of the functional role of the Audit Committee is the fourth most disclosed information (88\%). Moreover, the fifth most disclosed information is information about bank statements $(83 \%)$, while the description of the main products and/or services provided by the bank and awards won were $79 \%$. The last three most disclosed information topics are the number of meetings held with the Audit Committee during the year, their study about work they carried out and the names, ages and addresses of the Board of Directors (75\%).

Table 11 shows the percentage of the voluntary disclosure of banks listed on the Bahrain Bourse. It shows that the largest bank that provides voluntary disclosures is the National Bank of Bahrain, which discloses $70 \%$, followed by the Bank of Bahrain and Kuwait (65\%) and then Bahrain Islamic Bank with a percentage of 55\%, while the

\begin{tabular}{|c|c|c|c|}
\hline No & Disclosure Type & \# of Banks & $\%$ \\
\hline 1 & The experience of managers & 7 & $29 \%$ \\
\hline 2 & Managers' educational certificates & 4 & $17 \%$ \\
\hline 3 & Dividing managers to executive and non-executive director & 5 & $21 \%$ \\
\hline 4 & Study of the responsibility of managers in the preparation of financial research & 0 & $0 \%$ \\
\hline & Average Total & \multicolumn{2}{|c|}{$17 \%$} \\
\hline
\end{tabular}

Table 5: Information about senior management.

\begin{tabular}{|c|c|c|c|}
\hline No & Disclosure Type & \# of Banks & $\%$ \\
\hline 1 & Summary of financial statements for the last three years or more & 15 & $63 \%$ \\
\hline 2 & Information about the share price & 24 & $100 \%$ \\
\hline 3 & Attaching the adjusted financial statements after taking into account inflation and its impact on it & 14 & $58 \%$ \\
\hline 4 & The impact of inflation on the future of the bank's operations & 12 & $50 \%$ \\
\hline 5 & Bank loans and mortgages and their uses & 16 & $67 \%$ \\
\hline 6 & Advertising expenses & 2 & $8 \%$ \\
\hline 7 & Information about fluctuations in foreign currency exchange rates during the year & 17 & $71 \%$ \\
\hline 8 & Information that may affect the future performance of the bank & 5 & $21 \%$ \\
\hline 9 & Disclosure of any new products and services & 16 & $67 \%$ \\
\hline 10 & The marketing plan and the plan's expansion in the distribution system & 6 & $25 \%$ \\
\hline 11 & The expansion plan of sales & 7 & $29 \%$ \\
\hline 12 & The impact of the bank's strategy on future business results & 8 & $33 \%$ \\
\hline 13 & Disclosure of research and development (R\&D) expenditure & 7 & $29 \%$ \\
\hline 14 & Statement of cash flows & 24 & $100 \%$ \\
\hline 15 & Disclosure of the expected expenses for advertising & 7 & $29 \%$ \\
\hline 16 & Expectations of profitability per share for each share & 15 & $63 \%$ \\
\hline 17 & Forecasts of future sales & 12 & $50 \%$ \\
\hline 18 & Statement of capital expenditures expected & 18 & $75 \%$ \\
\hline 19 & Forecasts of future profits & 12 & $50 \%$ \\
\hline & Average Total & \multicolumn{2}{|c|}{$52 \%$} \\
\hline
\end{tabular}

Table 6: Disclosures about financial and non-financial analysis. 
Citation: Awadh M, Alareeni B (2018) Measuring Level of Voluntary Disclosures of Banks Listed in Bahrain Bourse. J Account Mark 7: 295. doi: 10.4172/2168-9601.1000295

Page 9 of 12

\begin{tabular}{|c|c|c|c|}
\hline No & Disclosure Type & \# of Banks & $\%$ \\
\hline 1 & Total number of employees for the last two years or more & 5 & $21 \%$ \\
\hline 2 & Classification of employees by gender & 9 & $38 \%$ \\
\hline 3 & The number of bonuses granted to employees and the policy for granting them. & 9 & $38 \%$ \\
\hline 4 & Categories and the quality of the staff who have received training in the bank & 9 & $38 \%$ \\
\hline 5 & Policy used in training & 6 & $25 \%$ \\
\hline 6 & The budget for staff training expenses & 3 & $13 \%$ \\
\hline 7 & Reasons for the change in the number of employees & 7 & $29 \%$ \\
\hline 8 & Educational qualifications of accountants & 8 & $33 \%$ \\
\hline 9 & Disclosures for work accidents & 5 & $21 \%$ \\
\hline 10 & Social security policy & 4 & $17 \%$ \\
\hline 11 & Employment rotation policy & 10 & $42 \%$ \\
\hline 12 & Employment policies & 9 & $38 \%$ \\
\hline 13 & Disclosure of the safety and security system & 6 & $25 \%$ \\
\hline 14 & The cost of safety and security procedures & 5 & $21 \%$ \\
\hline 15 & The company's social contributions & 13 & $54 \%$ \\
\hline 16 & Environmental protection programs & 1 & $4 \%$ \\
\hline 17 & Subsidies and contributions to others & 3 & $13 \%$ \\
\hline 18 & Donations and grants & 14 & $58 \%$ \\
\hline & Average Total & \multicolumn{2}{|c|}{$29 \%$} \\
\hline
\end{tabular}

Table 7: Information about employees of the bank and disclosure of social responsibility and environmental policies.

\begin{tabular}{|c|l|c|c|}
\hline No & \multicolumn{1}{|c|}{ Disclosure Type } & \# of Banks & \% \\
\hline 1 & Study and development policy & 4 & $17 \%$ \\
\hline 2 & Number of employees working in study and development & 6 & $25 \%$ \\
\hline 3 & Financial allocations for study and development & 2 & $8 \%$ \\
\hline 4 & The actual cost of R\&D activities during the previous two years & 6 & $25 \%$ \\
\hline 5 & R\&D projects & 9 & $38 \%$ \\
\hline 6 & The achieved results of study and development & 6 & $25 \%$ \\
\hline & Average Total & $\mathbf{2 3 \%}$ \\
\hline
\end{tabular}

Table 8: R\&D costs

\begin{tabular}{|c|l|c|}
\hline No & \multicolumn{1}{|c|}{ Disclosure Type } & $\%$ \\
\hline 1 & General information about banks & \\
\hline 2 & Disclosures about financial and non-financial analysis & $54 \%$ \\
\hline 3 & Information about the Audit Committee & $52 \%$ \\
\hline 4 & Disclosures of the Board of Directors & $45 \%$ \\
\hline 5 & Information about employees of the bank and disclosure of social responsibility and environmental policies & $42 \%$ \\
\hline 6 & Information about governance & $29 \%$ \\
\hline 7 & R\&D costs & $28 \%$ \\
\hline 8 & Information about senior management & $23 \%$ \\
\hline
\end{tabular}

Table 9: Summary of the main eight group disclosures (Eight panels).

Bahrain Development Bank and the Mashreq Bank demonstrated less disclosure (only $27 \%$ and $26 \%$, respectively). This demonstrates that some banks operating in Bahrain and listed on the Bahrain Bourse are knowledgeable about voluntary disclosure benefits and are seeking to increase them. While the majority of banks provides between $30 \%$ and $50 \%$ of voluntary disclosure, those may lack the knowledge about its benefits for them and their investors. In addition, it is remarkable that the analysis demonstrates that the average level of voluntary disclosures of all listed banks in Bahrain is weak, with its average equaling $41 \%$.

To summarize, an approximately most of banks operating in Bahrain are disclosing voluntary information. but the level of disclosure is varying from one bank to another. Most of the banks are disclosing general information about the bank (54\%) and the highest information disclosed of general information is the bank historical information
(92\%) and the lowest information disclosed is about the effects of political and economic factors on the results of the bank's business (8\%). While the second most disclosed information is about financial and non-financial analysis (52\%) and the highest information disclosed about it is statements of cash flows as well as the share price (100\%). However, the lowest information disclosed is advertising expenses (8\%). The third most disclosed information is about audit committee (45\%) and the highest disclosing information in this topic is about functional role of the audit committee (88\%). While, the independence of the audit committee and the number of attendees at their meeting were not been disclose. The fourth most disclosed is information about board of directors (42\%) and in this topic, the names, ages and addresses of the board of directors are highest disclosed information (75\%). and the amount of the board members contribution as well as the methods of determining bonuses and compensation to the board members has been 
Citation: Awadh M, Alareeni B (2018) Measuring Level of Voluntary Disclosures of Banks Listed in Bahrain Bourse. J Account Mark 7: 295. doi: 10.4172/2168-9601.1000295

Page 10 of 12

\begin{tabular}{|c|l|c|c|}
\hline No & \multicolumn{1}{|c|}{ Disclosure Type } & \# of Banks & $\%$ \\
\hline 1 & Information about share price & 24 & $100 \%$ \\
\hline 2 & Statement of cash flows & 24 & $100 \%$ \\
\hline 3 & A brief summary of historical information about the bank & 22 & $92 \%$ \\
\hline 4 & Declaration of functional role of the Audit Committee & 21 & $88 \%$ \\
\hline 5 & Disclosure of bank statement & 20 & $83 \%$ \\
\hline 6 & Description of the main products/services provided by the bank & 19 & $79 \%$ \\
\hline 7 & Awards won by the bank & 19 \\
\hline 8 & Number of meetings held with the Audit Committee during the year & 18 & $79 \%$ \\
\hline 9 & A study about work carried out by the Audit Committee & 18 & $75 \%$ \\
\hline 10 & The names, ages and addresses of the Board of Directors & 18 & $75 \%$ \\
\hline
\end{tabular}

Table 10: Summary of the most 10 disclosed information topics.

\begin{tabular}{|c|c|c|c|c|}
\hline No. & Banks in Bahrain & $\begin{array}{l}\text { Number of items of disclosed } \\
\text { information }\end{array}$ & $\begin{array}{c}\text { Number of voluntary items in } \\
\text { the list }\end{array}$ & The percentage of disclosure \\
\hline 1 & National Bank of Bahrain & 59 & 84 & $70 \%$ \\
\hline 2 & Bank of Bahrain and Kuwait & 55 & 84 & $65 \%$ \\
\hline 3 & Bahrain Islamic Bank & 46 & 84 & $55 \%$ \\
\hline 4 & Standard Chartered Bank & 45 & 84 & $54 \%$ \\
\hline 5 & Citibank & 41 & 84 & $49 \%$ \\
\hline 6 & Ahli United Bank & 40 & 84 & $48 \%$ \\
\hline 7 & Kuwait Finance House & 40 & 84 & $48 \%$ \\
\hline 8 & Al Baraka Islamic Bank & 39 & 84 & $46 \%$ \\
\hline 9 & Ithmaar Bank & 36 & 84 & $43 \%$ \\
\hline 10 & Arab Bank & 35 & 84 & $42 \%$ \\
\hline 11 & Khaleeji Commercial Bank & 34 & 84 & $40 \%$ \\
\hline 12 & United Gulf Bank & 33 & 84 & $39 \%$ \\
\hline 13 & Al-Salam Bank & 33 & 84 & $39 \%$ \\
\hline 14 & BMI Bank & 31 & 84 & $37 \%$ \\
\hline 15 & HSBC Bank Middle East & 31 & 84 & $37 \%$ \\
\hline 16 & National Bank of Abu Dhabi & 29 & 84 & $35 \%$ \\
\hline 17 & Habib Bank & 28 & 84 & $33 \%$ \\
\hline 18 & Eskan Bank & 27 & 84 & $32 \%$ \\
\hline 19 & State Bank of India & 27 & 84 & $32 \%$ \\
\hline 20 & National Bank of Kuwait & 26 & 84 & $31 \%$ \\
\hline 21 & BNP Paribas & 24 & 84 & $29 \%$ \\
\hline 22 & ICICI Bank & 24 & 84 & $29 \%$ \\
\hline 23 & Bahrain Development Bank & 23 & 84 & $27 \%$ \\
\hline 24 & Mashreq Bank & 22 & 84 & $26 \%$ \\
\hline \multicolumn{4}{|c|}{ Average } & $41 \%$ \\
\hline
\end{tabular}

Table 11: The level of voluntary disclosures of each bank and for all banks on average.

the lowest disclosed information (17\%). Information about employees of the bank, disclosure of social responsibility and environmental policies are the fifth most disclosed information (29\%) and the highest disclosed information about the topic are: donations and grants (58\%), the bank social contribution (54\%) and employment rotation policy (42\%). However, a one percentage disclosure was disclosed about the environmental protection programs. The sixth most disclosed topic is about governance (28\%). And highest information disclose about it is the number of meetings during the year (38\%). And the lowest disclosed information is the responsibilities of the governance committee and the abiding by the rules of governance (21\%). Whereas, the seventh most disclosed topic is research and developments costs $(23 \%)$ and the highest information disclose about it is research and developments projects (38\%). And disclosure of the study and development policy was the lowest disclosure (17\%). Finally, the eighth most disclosed topic is about senior management (17\%) and highest information disclose about is the experience of managers (29\%). However, no disclosures were published by any bank about the responsibility of managers in preparation of financial research. Additionally, the findings showed that the largest bank that provides voluntary disclosures is the National Bank of Bahrain (70\%), followed by the Bank of Bahrain and Kuwait $(65 \%)$ and then Bahrain Islamic Bank with a percentage of 55\%.

\section{Conclusion}

It has been shown that the largest bank that provides voluntary disclosures is the National Bank of Bahrain, which discloses $70 \%$, followed by the Bank of Bahrain and Kuwait at $65 \%$ and then Bahrain Islamic Bank with a percentage of 55\%, while the Mashreq Bank had the least disclosure at only $26 \%$.

However, the overall percentage of voluntary disclosure in all banks in the market as a whole is $46 \%$. In addition, the findings showed that the most disclosed information is general information about banks (54\%) and information about financial and non-financial analysis 
(52\%), such as information about the share price (100\%) and historical information about the bank (92\%).

Further, the study showed that there is a lack of willingness by banks to disclose multiple information, such as: information about employees of the bank and disclosure of social responsibility and environmental policies (29\%), information about governance $(28 \%)$, information about R\&D costs $(23 \%)$ and information about senior management (17\%).

In general, the results showed that there is a difference and variation in the level of the voluntary disclosure of information from one bank to another.

Based on previous results, we recommend that Banks need to increase the level of voluntary disclosure in order to gain multiple benefits as we aforementioned. In addition, Bahrain Bourse should encourage banks to disclose voluntary information by providing an evaluation for it. Furthermore, conferences and workshops should be held to highlight the importance and the benefits of voluntary disclose to enhance the annual research and other benefits for banks as well as for the users.

Future research should be focused on the following: measuring voluntary disclosure of the bank sector in other than annual reports, such as conferences, bank websites and newspapers. Another study can be done about voluntary disclosure of other than banking sectors in Bahrain and the factors impacting and influencing the voluntary disclose levels in addition to a study about how to encourage organizations (those listed and unlisted on the Bahrain Bourse) to disclose more information.

\section{References}

1. Gray SJ, Meek GK, Roberts CB (1995) International capital market pressures and voluntary annual report disclosures by US and UK multinationals. J Inter Financial Manag Acc 6: 43-68.

2. Yuen CY, Liu M, Zhang X, Lyu C (2009) A case study of voluntary disclosure by Chinese enterprises. Asian J Finance Acc 1: 1-28.

3. Alareeni B, Branson J (2011) The relative performance of auditors' goingconcern opinions and statistical failure prediction models in Jordan. Acc Bedr 31: 23-35.

4. Hamada R (2014) Measure the impact of the optional disclosure in the quality of financial reporting - a field study in the Amman Stock Exchange. Jordan J Business Administration 10: 698-674.

5. Hasan T, Hosain Z (2015) Corporate Mandatory and Voluntary Disclosure Practices in Bangladesh: Evidence from listed companies of Dhaka Stock Exchange. Res J Finance Acc 6: 14-32.

6. Alareeni B (2017) The association between audit firm characteristics and audit quality: A meta-analysis.

7. Fung B (2014) The demand and need for transparency and disclosure in corporate governance. Universal Journal of Management 2: 72-80.

8. Ho SS, Wong KS (2001) A study of corporate disclosure practice and effectiveness in Hong Kong. J Inter Financial Management and Accounting 12 75-102.

9. Mitton T (2002) A cross-firm analysis of the impact of corporate governance on the East Asian financial crisis. J Financial Economics 64: 215-241.

10. Bushman RM, Smith AJ (2001) Financial accounting information and corporate governance. J Accounting and Economics 32: 237-333.

11. Alareeni B, Deghish H (2016) Applicability of the balanced scorecard to assess aerformance of Al-Aqsa Media Network Institution in Gaza Strip. IUG J Economics and Business.

12. Hossain M (2008) The extent of disclosure in annual reports of banking companies: the case of India. Eur J Scientific Res 23: 659-680.
13. Luckins J, Abeysekera I, Chew TG, Egan T, Ghandar A, et al. (2012) A guide to understanding annual reports: listed companies.

14. Hamad M (2010) Accounting and its importance in light of the application of the Egyptian accounting and the requirements of the law 91 of 2005. College of Suez Canal University, Egypt.

15. Abeywardana NLE, Panditharathna KM (2016) The Extent and Determinants of Voluntary Disclosures in Annual Reports: Evidence from Banking and Finance Companies in Sri Lanka. Accounting and Finance Research 5: 147-162.

16. Zhang Z, Zhang J (2014) Analysis on Voluntary Disclosure of Accounting Information for Listed Companies in China. Inter Business and Management 9: $143-148$.

17. Hazem KS (2014) Other optional accounting disclosure in the financial reports on the rationalization of the decisions of investors in industrial companies listed on the Amman Stock Exchange: An empirical study, Master thesis, Alzarqa University.

18. Shehata NF (2014) Theories and determinants of voluntary disclosure Accounting and Finance Research 3: 18-26.

19. Alareeni B, Aljuaidi O (2014) The Modified Jones and Yoon Models in detecting earnings management in Palestine Exchange (PEX). Inter J Innovation and Applied Studies 9: 2028-9324.

20. Mutiva JM, Ahmed A, Ndirangu MJW (2015) The Relationship between Voluntary Disclosure and Financial Performance of Companies Quoted at the Nairobi Securities Exchange. Inter J Managerial Studies and Res 3: 171-195.

21. Jizi M, Nehme R, Salama A (2016) Do social responsibility disclosures show improvements on stock price? The J Developing Areas 50: 77-95

22. Moghaddam A, Khorami M, Masoomi T, Alidoost F, Arasteh S et al. (2014) Effect Of Voluntary Disclosure On Stock Prices Of Listed Firms In Tehran Stock Exchange. Applied Mathematics in Eng Management and Tech 2: 449-454.

23. Abbadi AM (2017) The Impact of Voluntary Disclosure on Stock Liquidity in Jordanian. Zarqa University J Research and Human Studies pp: 1-78.

24. Asongu S (2013) Post-crisis bank liquidity risk management disclosure Qualitative Research in Financial Markets 5: 65-84.

25. Khan MAA, Abera HB (2015) The Determinants and Characteristics of Voluntary Disclosure by Ethiopian Banks. Sumedha J Management 4: 4-20.

26. Shaqqour O (2013) Accounting transparency in the Jordanian Islamic banks and the factors influencing them. Master thesis, Zarqa University 1-120.

27. Abdullah WAW, Percy M, Stewart J (2015) Determinants of voluntary corporate governance disclosure: Evidence from Islamic banks in the Southeast Asian and the Gulf Cooperation Council regions. J Contemporary Acc and Economics 11: $262-279$

28. Hossain M, Reaz M (2007) The determinants and characteristics of voluntary disclosure by Indian banking companies. Corporate Social Responsibility and Environmental Management 14: 274-288.

29. Hossain M, Hammami $H$ (2009) Voluntary disclosure in the annual reports of an emerging country: the case of Qatar. Advances in Accounting 25: 255-265.

30. Qiu Y, Shaukat A, Tharyan R (2016) Environmental and social disclosures: Link with corporate financial performance. The British Accounting Review 48 : 102-116.

31. Petrova E, Georgakopoulos G, Sotiropoulos I, Vasileiou KZ (2012) Relationship between cost of equity capital and voluntary corporate disclosures. Inter Economics and Finance 4: 83-96.

32. Poshakwale S, Courtis JK (2005) Disclosure level and cost of equity capital: Evidence from the banking industry. Managerial and Decision Economics 26: 431-444.

33. Casey J, O'Mahoney O (2011) An Analysis of the Determinants of Voluntary Impairment Disclosure.

34. Aikaeli J, Rashid Z (2015) Relationship between Profitability and Voluntary Disclosure: A Case of Banks in Kenya pp: 1-25.

35. Achoki IN, Shukla J (2016) Effect of voluntary disclosure on the financial performance of commercial banks in Rwanda. A study on selected banks in Rwanda. Eur J Business and Social Sci 5: 167-184.

36. Kendi MJ, Mwangi M (2014) The effect of voluntary disclosure on stock marke returns of companies listed on the Nairobi securities exchange. Inter J Business and Social Sci 6: 99-105 
Citation: Awadh M, Alareeni B (2018) Measuring Level of Voluntary Disclosures of Banks Listed in Bahrain Bourse. J Account Mark 7: 295. doi: 10.4172/2168-9601.1000295

37. Hawashe A (2015) Voluntary Information Disclosure in the Annual Reports of Libyan's Commercial Banks: A Longitudinal Analysis Approach. Eur J Accounting, Auditing and Finance Res 4: 22-48.

38. Barac ZA, Granic M, Vuko T (2014) The determinants of Voluntary disclosure in Croatia. World Academy of Science, Engineering and Technology. Inter J Social, Behavioral, Educational, Economic, Business and Industrial Eng 8: 1057-1063.

39. Feyitimi O (2014) The level of financial information disclosure and corporate attributes in developing economy. Eur J Business and Manag 6: 176-188.

40. Jankauskienè V, Kaupelytè D, Legenzova R (2012) Limitations of Financial Disclosure: Case of Bank Snoras Bankruptcy. Economics and Management 17: 829-835

41. Oluwagbemiga $E$ (2014) The use of voluntary disclosure in determining the quality of financial statements: Evidence from the Nigeria listed companies. Serbian J Management 9: 263-280.

42. Zer Ilknur (2015) Information Disclosures, Default Risk, and Bank Value, Finance and Economics Discussion Series 2015-104. Washington: Board of Governors of the Federal Reserve System.

43. Hawashe AAM (2016) Commercial Banks' Attributes and Annual Voluntary Disclosure: The case of Libya. Inter J Accounting and Financial Reporting 5 : 208-233.

44. Mensah BKA (2012) Association between firm-specific characteristics and levels of disclosure of financial information of rural banks in the Ashanti region of Ghana. J Applied Finance and Banking 2: 69.
45. Bhasin M, Makarov R, Orazalin N (2012) Determinants of voluntary disclosure in the banking sector: An empirical study. Inter J Contemporary Business Studies 3: 110-120.

46. Costa ILDS, Correia TDS, Paulo E, Lucena WGL (2017) O Impacto do Disclosure Voluntário: O Valor da Empresa e as Informações Socioambientais nas companhias abertas. Revista Contabilidade, Gestão e Governança 21 : 271-287.

47. Barako DG, Hancock $P$, Izan HY (2006) Factors influencing voluntary corporate disclosure by Kenyan companies. Corporate Governance: An International Review 14: 107-125

48. Healy PM, Palepu KG (2001) Information asymmetry, corporate disclosure, and the capital markets: A review of the empirical disclosure literature. J Accounting and Economics 31: 405-440.

49. Isaac MAI, Felix N, Felix AN (2016) Board Composition, Firm Size, Audit Type and Voluntary Disclosure of Forward Looking Information in the Banking Sector: Evidence from Nigeria. Research J Finance and Acc 7: 23-29.

50. Musyoka MN (2017) Effect of Voluntary Disclosure on Financial Performance of Firms Listed At Nairobi Securities Exchange (Doctoral dissertation, KCA University).

51. Frino A, Palumbo R, Capalbo F, Gerace D, Mollica V (2013) Information disclosure and stock liquidity: evidence from Borsa Italiana. Abacus 49: 423-440.

52. Alqallaf H, Alareeni B (2018) Evolving of Selected Integrated Reporting Capitals among Listed Bahraini Banks. Journal of Accounting and Applied Business Research 1: 1-21. 